\title{
Refleksyjność wyzwaniem współczesnego świata
}

\author{
Reflexivity: \\ the Challenge of the Modern World
}

\begin{abstract}
ABSTRAKT
Szybki postęp cywilizacyiny i elektroniczny, rozwój świata wirtualnego, który nastapił w XXI wieku, zmienił sposób bycia i funkcjonowania człowieka. W sytuacji powiększającej się autonomii osoby w zakresie dostępu do informacji, a także oczekiwań w zakresie samodzielności w kreowaniu własnego rozwoju, zagadnienie refleksyiności nabiera szczególnego znaczenia. Tym bardziej, że dostrzegalne współcześnie deficyty refleksyjności budzq niepokój dotyczq̨cy indywidualnego rozwoju osoby. Dlatego przedmiotem teoretycznej analizy będzie zagadnienie refleksyjności w odniesieniu do aksjonormatywnego chaosu, jaki jest obecny w świecie. Zostanq omówione wymiary refleksyjności, następnie przedstawiona będzie koncepcja odnoszq̨ca się do refleksyiności i bezrefleksyiności oraz ukazana zostanie refleksyjność jako ważne zadanie rozwojowe.
\end{abstract}

\section{ABSTRACT}

The rapid civilizational progress and development of the virtual world that has taken place in the 21 st century has changed the manner of being and functioning of human beings. In a situation of growing

Articles and dissertations
SLOWA KLUCZOWE refleksyjność, bezrefleksyiność, myślenie refleksyjne, społeczeństwo informacyine

\section{KEYWORDS}

reflexivity, unreflectivity, reflective thinking, information society
SPI Vol. 21, 2018/4

ISSN 2450-5358

e-ISSN 2450-5366 DOI: 10.12775/SPI.2018.4.003

Nadestano: 26.10 .2018 Zaakceptowano: 10.12 .2018

Artykuły i rozprawy 
autonomy of the person in the field of access to information, as well as expectations in the field of independence in creating their own development, the issue of reflexivity has become particularly important. This is all the more so given the fact that the reflective deficits of today are arousing concern about individual personal development. Therefore, the subject of theoretical analysis will be the issue of reflexivity in relation to the axionormative chaos that is present in the world. The dimensions of reflexivity will be discussed, before the concepts relating to reflexivity and unreflectivity are presented, with reflexivity shown as an important development task.

\section{Wprowadzenie}

Szybki postęp cywilizacyjny i elektroniczny oraz rozwój świata wirtualnego, który nastąpił w XXI wieku, zmienił sposób bycia i funkcjonowania człowieka. Można zauważyć, że zewsząd otaczają go skomplikowane urządzenia, a informatyka i elektronika są niemalże wszechobecne. W wyniku tych zmian życie współczesnego człowieka zostało zdominowane między innymi przez coraz częstsze korzystanie z sieci. Trzeba zaznaczyć, że żyjąc w tak stechnicyzowanym świecie człowiek ma wiele niezwykłych i nieznanych dotąd możliwości, może więc działać sprawniej i efektywniej. Jednak żyje coraz bardziej chaotycznie, w poczuciu psychicznej dezorientacji i zamieszaniu, często jest niespokojny, zmęczony, zestresowany, sfrustrowany i nieszczęśliwy. Jak słusznie zauważa Maria Jagiełło, „obok rozmachu i progresu pojawiły się niepokojące zjawiska, które uwydatniają ludzką bezradność wobec zatracania się w konsumpcyjnym stylu życia, w modusie posiadania, w instrumentalizacji międzyludzkich relacji” ${ }^{1}$ W społeczeństwie informacyjnym można zaobserwować również pewien paradoks komunikacji, który polega na tym, że im bardziej komunikacja jest zglobalizowana i standaryzowana, tym bardziej przyczynia się do izolacji osoby. Można też stwierdzić, że im bardziej jest masowa, tym mniej jest ludzka, a im jest szersza, to tym bardziej zawęża osobowościowe doświadczenie człowieka. „Postęp związany z rozwojem Internetu, elektroniki, mediów masowych,

1 M. Jagiełło, Spotkania, które zmieniaja. O spotkaniu jako kategorii pedagogicznej i wydarzeniu wychowujacym na drodze życia, Kraków 2012, s. 9-10. 
telefonów przenośnych i innych udogodnień umożliwia natychmiastowość, zmienia stosunek do czasu, tradycji, ale także przeżyć i doświadczeń relacji z innymi”'. Niewątpliwie, ten gwałtowny rozwój nowych technologii prowadzi także do niekorzystnych zmian w strukturze społecznej, kulturze, systemie wartości i norm. Poważnym zagrożeniem XXI wieku jest „atrofia systemów aksjonormatywnych, liberalizacja regulatorów życia społecznego oraz zmniejszenie stopnia ich egzekwowania w dziedzinie obyczajowości i moralności”3. Dlatego też coraz częściej zwraca się uwagę na problem degradacji wartości humanistycznych. A przecież to właśnie wartości decydują o rozwoju osobowym człowieka i są wyznacznikami jego życiowych dążeń i wyborów. „Wartość jest wzorcem i domaga się urzeczywistnienia w ludzkim czynie"4. Istotnie współcześnie obserwujemy aksjonormatywny chaos, który ma negatywne konotacje i kojarzy się z bałaganem i dezorganizacją, utratą znaczeń dotychczas wyznawanych wartości i środków ich osiągania, nasileniem się procesów indywidualizacyjnych.

Niepokój wzbudza również rezultat badań psychologicznych nad refleksyjnością, prowadzonych przez Ellen Langer, z których wynika, że bezrefleksyjność czy bezmyślność stają się coraz częstszym i powszechnym zjawiskiem ${ }^{5}$.

W sytuacji powiększającej się autonomii osoby w zakresie dostępu do informacji, a także oczekiwań w zakresie samodzielności w kreowaniu własnego rozwoju, zagadnienie refleksyjności nabiera szczególnego znaczenia. Można zaobserwować, że obecnie człowiek $\mathrm{w}$ codziennym życiu unika systematycznej refleksji i autorefleksji i często poprzestaje na wglądzie we własne zachowanie dopiero wtedy, kiedy doświadcza niepowodzeń, porażek lub przeżywa momenty

2 K. Lasocińska, Niecodzienna codziennosí - globalizacja wyzwaniem do refleksyjnego konstruowania wtasnej biografii, „Civitas Hominibus. Rocznik Filozoficzno-Społeczny" 2011, nr 6, s. 47.

3 I. Przyby1, Refleksje profesora Zbigniewa Tyszki nad cztowiekiem i rodzina XXI wieku, „Roczniki Socjologii Rodziny” 2005, t. 16: Dylematy wspótczesnych rodzin, s. 247.

4 A. Regulska, Rola wartości moralnych w procesie wychowania, „Studia nad Rodziną" 2013, t. 17, nr 1(32), s. 148.

5 Zob. E. Langer, Problemy uświadamiania. Konsekwencje refleksyjności i bezreAleksyjności, w: Poznanie. Afekt. Zachowanie, red. T. Maruszewski, Warszawa 1993. 
trudne i traumatyczne. W związku z tym, przedmiotem teoretycznej analizy będzie zagadnienie refleksyjności w odniesieniu do aksjonormatywnego chaosu, jaki jest obecny w świecie. W pierwszej kolejności zostaną omówione wymiary refleksyjności, następnie koncepcja odnosząca się do refleksyjności i bezrefleksyjności, oraz refleksyjność jako ważne zadanie rozwojowe.

\section{Wymiary refleksyjności}

Pojęcie refleksyjnośc jest złożone, wielowymiarowe i trudne do zdefiniowania. W potocznym rozumieniu termin ten bywa łączony z dojrzałością, świadomością i mądrością. Nie jest on zdefiniowany w Encyklopedii pedagogicznej XXI wieku, natomiast opracowane zostało pojęcie refleksji, określone jako „czynność umysłu polegająca na ujmowaniu lub tylko uświadamianiu własnych aktów (w tym samej refleksji) w aspekcie ich istnienia, zawartości, struktury i przebiegu”. To również świadomy proces myślowy będący „podstawową cechą świadomości”’.

W ogólnym znaczeniu termin refleksyjnośc definiowany jest jako „kkłonność do refleksji, do zastanawiania się, rozważania, analizowania”. Jest to także „zdolność do analizowania uzyskiwanych doświadczeń oraz włączania nowych danych, informacji, wiedzy do posiadanych struktur poznawczych i tworzenia nowych powiązań wiedzy z działaniem"

W szerokim ujęciu refleksyjność to „wszelka aktywność intelektualna (epistemiczna), a także - w niektórych koncepcjach - związana $\mathrm{z}$ nią aktywność motywacyjno-emocjonalna (uwzględniająca pragnienia, cele, intencje), która zmierza do poznania czegoś: przedmiotu zewnętrznego lub własnej aktywności świadomościowej, czyli wszystkiego, co znajdzie się w polu ludzkiej świadomości" ${ }^{10}$. Należy

6 W. Chudy, Refleksja, w: Encyklopedia pedagogiczna XXI wieku, t. 5, red. T. Pilch, Warszawa 2006, s. 69.

7 Tamże, s. 68-69.

8 Refleksyjnośc, w: Stownik jezzyka polskiego, red. M. Szymczak, Warszawa 1981, s. 32 .

9 T. Hejnicka-Bezwińska, Pedagogika ogólna, Warszawa 2008, s. 502.

10 D. Słaba, Wokót zagadnień refleksyjności w rozwoju cztowieka dorostego, „Chowanna” 2014, nr 2(43), s. 322. 
zauważyć, że refleksyjność wyróżnia się dociekliwością, i polega między innymi na rozpatrywaniu spraw w świetle ich uwarunkowań i konsekwencji.

Ponadto trzeba zaznaczyć, że refleksyjność jest różnie omawiana $\mathrm{w}$ aspekcie filozoficznym, socjologicznym, teologicznym, psychologicznym oraz pedagogicznym. Istnieje wiele wymiarów refleksyjności, niemniej ogólnie można wskazać na trzy podstawowe ujęcia. W wymiarze poznawczym podkreśla się związek refleksyjności z formami myślenia, procesami uczenia się i profesjonalizacją. Refleksyjność powstaje bowiem na bazie ogólnych zdolności poznawczych między innymi operacji intelektualnych. Następnie refleksyjność określana jest jako ogólna cecha człowieka, która prowadzi do samoświadomości i podmiotowości. Z kolei refleksyjność jako wymóg współczesnych czasów uobecnia się jako kluczowa kompetencja, która jest potrzebna i konieczna do egzystencji w świecie ponowoczesnym. Zdaniem Immanuela Maurice’a Wallersteina, to właśnie świat z końca XX i z początku XXI wieku jest światem refleksyjności ${ }^{11}$.

Refleksyjne myślenie, którego cechą jest systematyczność, rygoryzm i zdyscyplinowanie, ma również wymiar społeczny, bowiem odbywa się w interakcji z innymi. Można twierdzić, iż wiedza i indywidualne doświadczenia człowieka sprawiają, że jego umysł się doskonali, niemniej o głębi i pięknie osoby można przekonać się w wyniku interakcji, komunikacji z drugim człowiekiem. Dlatego ważne jest również przedstawienie tego wymiaru refleksyjności.

Obecnie bariery, takie jak czas i przestrzeń, które ograniczały komunikację międzyludzką, zostały opanowane, a to spowodowało, że dostępność tych narzędzi zintensyfikowała skalę komunikacji masowej i interpersonalnej. Wzrosło natomiast zagrożenie i trudności w komunikowaniu się, gdyż człowiek zaczął działać natychmiastowo, bardzo często tylko na podstawie emocji i doznań zmysłowych. W tym kontekście bardzo ważne wydaje się stwierdzenie, że:

[...] doświadczenie siebie i otaczającego świata oraz uczenie się siebie i otaczającego świata posiada zatem swój szczególny horyzont i kontekst - obecności drugiego człowieka jako kogoś nieredukowalnie innego w swej zewnętrzności istnienia, ale zarazem nieredukowalności bycia „obok”, „naprzeciw” oraz w „obrębie” tego samego czasu i miejsca.

11 Zob.I.M. Wallerstein, Koniec świata jaki znamy, przeł. M. Bilewicz, A.W. Jelonek, K. Tyszka, Warszawa 2004. 
Człowiek dzieli więc czas i miejsce $\mathrm{z}$ innym człowiekiem, to zaś staje się źródłem jego bezpieczeństwa lub zagrożenia, wspólpracy lub rywalizacji, wsparcia lub dyskredytacji - odczuwania i przeżywania swojskości i wspólnotowości lub obcości i antagonizmu ${ }^{12}$.

Jak słusznie zauważa Elżbieta Sujak,

[...] jest jakaś tajemnica w każdym spotkaniu z drugim człowiekiem. Tymczasem całe życie składa się z takich spotkań: koniecznych, przypadkowych, poszukiwanych, niekiedy nawet starannie przygotowanych. Inne zaś są nieuniknione, choć chciałoby się wymknąć cichaczem, minąć człowieka budzącego niepokój. Każde spotkanie z drugim człowiekiem zawiera zarówno szansę, jak i zagrożenie rozwoju: każde z nich czegoś nam udziela lub zabiera, otwiera nas lub zamyka, wzbogaca lub zuboża ${ }^{13}$.

Z niepokojem można zauważyć, że człowiek żyjący w społeczeństwie informacyjnym „coraz bardziej zaangażowany w aktywność zawodową, żyje pozorami wspólnoty, staje się samotny i zdany na powierzchowne sposoby łączności z innymi" ${ }^{14}$.

\section{Koncepcja refleksyjność a bezrefleksyjność}

Refleksyjność versus bezrefleksyjność w koncepcji Ellen Langer to podstawowe stany umysłu, odnoszące się do sposobu przetwarzania informacji w pierwszym zetknięciu się z nimi. Refleksyjność to stan, w którym osoba aktywnie dokonuje rozróżnień oraz tworzy nowe kategorie, wychodzi poza zastane struktury znaczeniowe, otwiera się na nowe informacje, zdaje sobie sprawę z wielości perspektyw patrzenia na daną sytuację i z możliwości ich zmiany. Przejawia się ona w elastyczności poznawczej, w dostrzeganiu różnych aspektów zjawisk i odmiennych sposobów ich rozumienia, w spostrzeganiu w nowy sposób znanych rzeczy. Jest wrażliwością na kontekst. Taki stan umożliwia szybkie reagowanie w przemyślany, zróżnicowany sposób oraz odpowiednio do sytuacji. Zdaniem Roberta J. Sternberga w takim ujęciu można wyróżnić cztery podstawowe

12 J. Gara, Egzystencjalna problematyzacja poszukiwania, poznawania i tworzenia samego siebie, „Przegląd Pedagogiczny” 2017, nr 2, s. 28.

13 E. Sujak, Rozważania o ludzkim rozwoju, Kraków 1987, s. 159.

14 M. Jagiełło, Spotkania, które zmieniajq. O spotkaniu jako kategorii pedagogicznej i wydarzeniu wychowujacym na drodze życia, dz. cyt., s. 10. 
komponenty refleksyjności: otwartość na nowość; dostrzeganie lub tworzenie nowych kategorii i rozróżnień; wrażliwość na różne konteksty; świadomość wielu perspektyw i punktów widzenia; orientacja na teraźniejszość ${ }^{15}$.

Z kolei bezrefleksyjność będzie się odnosiła do znikomego uświadamiania sobie procesu przyjmowania informacji, jak też ich znaczenia oraz alternatywnych kontekstów ich interpretacji. Takie niedostrzeganie zmiany skutkuje niemożnością intencjonalnego radzenia sobie z nowymi informacjami. Można stwierdzić, że jest to trzymanie się jednego kontekstu zastanych kategorii i rozróżnień, poruszanie się tylko na jednym poziomie analizy danego zjawiska, patrzenie tylko $z$ jednego punktu widzenia, trzymanie się zastanych lub utrwalonych znaczeń i interpretacji, niezależnie od zmiany kontekstu i tego, że przyjęte znaczenie ogranicza możliwości, obniża efektywność działania i poziom wykonania. Człowiek wykazuje się bezrefleksyjnością, gdy znaczenie danej informacji, mimo zmieniających się okoliczności lub zmiany kontekstu, odbiera jako niezmienne.

W odniesieniu do przedstawionej powyżej koncepcji refleksyjność - bezrefleksyjność warto przedstawić zagadnienie przekazu informacji, jaki odbywa się w społeczeństwie informacyjnym. Trzeba zaznaczyć, że rewolucja elektroniczna umożliwiła człowiekowi szeroki dostęp do niezbędnych, wręcz gotowych informacji, które są szybko pozyskiwane, ale równie szybko usuwane. „Postęp przyczynia się do ciągłej gonitwy za możliwościami, lękiem, żeby nie pozostać w tyle za innymi” ${ }^{16}$. Dlatego można zaobserwować chęć człowieka do tak zwanego bycia na bieżąco, na czasie. Pogoń za nowinkami, przewaga informacji nad wiedzą, skupianie uwagi na pojedynczych stwierdzeniach, duża ilość gotowych informacji powoduje, że człowiek nie doszukuje się w nich sensu i prawdy. Taka sytuacja nie skłania go do namysłu, zastanawiania się, analizy czy też rozważania danych faktów i zagadnień, nie prowadzi również do autoanalizy. A przecież informacje, które docierają do człowieka, modelują jego sposób myślenia, decydowania i działania. Obecnie człowiek poddawany jest bardziej informatyzacji niż komunikacji:

15 Por. R.J. Sternberg, Images of mindfulness, „Journal of Social Issues” 2000, nr 56, s. 11-26.

16 K. Lasocińska, Niecodzienna codziennosí - globalizacja wyzwaniem do refleksyjnego konstruowania wtasnej biografii, dz. cyt., s. 49. 
Nowa technologia na nowo definiuje podstawowe pojęcia, takie jak wiedza i prawda, programuje mechanizmy percepcyjne społeczeństwa decydujące o tym, co ważne, a co nieważne, co jest możliwe, a co niemożliwe, a także - przede wszystkim - co jest prawdziwe ${ }^{17}$.

Życie w informacyjnym świecie spowodowało także zmianę mentalności człowieka. Nasila się problem nie tylko analfabetyzmu w czytaniu, rozumieniu, pisaniu.

[Dotyczy to także] „analfabetyzmu mentalnego” określanego jako brak umiejętności posługiwania się zasadami i metodami ogólnej kultury poznawczej wspomagającej poznanie i myślenie, na którą składają się m.in.: krytyczny stosunek do posiadanej wiedzy, ujmowanie spraw w szerokim kontekście, patrzenie $\mathrm{z}$ wielu perspektyw, szukanie uwarunkowań i uzasadnień, przewidywanie konsekwencji, unikanie myślenia życzeniowego, szukanie dobrego poinformowania, refleksyjność ${ }^{18}$.

Można zatem stwierdzić, że „w świecie, pełnym głębokich zmian i modernizacji z udziałem wiedzy, refleksyjność staje się niezbędnym i koniecznym narzędziem nowej racjonalności myślenia i działania”19.

\section{Refleksyjność jako zadanie rozwojowe}

Rozwijanie refleksyjności wynika między innymi z prawidłowości rozwoju człowieka:

Rozwój operacji formalnych prowadzi do pojawienia się takich właściwości myślenia [...], jak: refleksyjność, krytycyzm, metaforyczne ujmowanie zdarzeń, niezależność od sądów innych osób, formułowanie własnych opinii. Cechy te z jednej strony umożliwiają refleksje nad własnym myśleniem, z drugiej zaś - uczestniczenie w dyskusjach ${ }^{20}$.

Myślenie refleksyjne kształtuje się w okresie wczesnej adolescencji i nabiera charakteru operacyjno-formalnego, co przejawia się

17 A. Bard, J. Soderquist, Netokracja. Nowa elita wtadzy i życie po kapitalizmie, przeł. P. Cypryański, Warszawa 2006, s. 127.

Z. Pietrasiński, Mądrość, czyli świetne ryposażenie umystu, Warszawa 2001, s. 53.

19

W. Dróżka, Kategorie analityczne w badaniach pedeutologicznych w siwietle zatożen refleksyjnych nurtórw poznawczych w naukach spotecznych, „Chowanna” 2006, t. 1(26), s. 31.

20 M. Kielar-Turska, Rozwój cztowieka w petnym cyklu życia, w: Psychologia. Podręcznik akademicki, t. 1: Podstawy psychologii, red. J. Strelau, Sopot 2003, s. 313-314. 
w dokonywaniu analizy i syntezy oraz wyciąganiu wniosków. Następnie rozwija się w okresie dorosłości, sięgając poziomu określanego operacjami post-formalnymi. Umiejętność dokonywania refleksji wydaje się być cechą osób dorosłych, bowiem mają one zwiększoną umiejętność autorefleksji. Również wyznaczanie celów życiowych oraz refleksja nad działaniem pozwalającym osiągnąć te cele są uważane za najważniejsze rozwojowo formy działalności człowieka we wczesnej dorosłości.

[S]topień refleksyjności danej jednostki ludzkiej decyduje często o jej sprawności intelektualnej i o morale - jak słusznie stwierdza Wojciech Chudy. - Ważne dla pedagogiki jest to, że to sama jednostka osobowa poznaje i rozstrzyga o ukierunkowaniu swojego działania $\mathrm{w}$ ujęciu aksjologicznym i etycznym, to zaś stanowi centralny element samowychowania ${ }^{21}$.

Należy podkreślić, że kompetencje refleksyjne w znacznym stopniu decydują o ogólnym rozwoju osobowościowym, w tym także etyczno-moralnym, gdyż skłonność do pogłębionego namysłu nad własnym działaniem oraz istotą poszczególnych elementów doświadczanej rzeczywistości ułatwia dokonywanie zmiany dotychczasowych przyzwyczajeń, pozwala na uwolnienie się od różnego typu deformacji poznawczych, zwiększa otwartość na odmienność przyjmowanych perspektyw i poglądów, uczy odpowiedzialności, ukierunkowuje uwagę na świat wartości. Natomiast obecnie można dostrzec, że w świecie kreowanym przez postęp technologiczny, elektroniczne iluzje, powierzchowną komunikację, władzę, pieniądze, ideologię samorealizacji i spełniania marzeń, relatywizm, niestety nie są promowane wartości, odpowiedzialność, więzi rodzinne, czy też praca nad sobą. A przecież „człowiekowi $z$ jednej strony potrzebny jest namysł i refleksja, które są podstawą mądrych decyzji, $z$ drugiej zaś brakuje mu refleksji nad samym sobą $i$ sensem życia. Dlatego tak ważne i konieczne są oddziaływania, które pomogą człowiekowi zatrzymać się i spojrzeć na swoje życie"22.

Refleksyjności sprzyja postawa, w której rozwój uznawany jest za cenną wartość. Osoba nie nabywa refleksyjności spontanicznie

21 W. Chudy, Refleksja, w: Encyklopedia pedagogiczna XXI wieku, dz. cyt., s. 72.

22 M. Chrost, Autorefleksyjnośc elementem samowychowania, w: Wychowanie - Socjalizacja - Edukacja. Ksiega Jubileuszowa dedykowana prof. dr. hab. Andrzejowi Michatowi de Tchorzewskiemu z okazji 75. rocznicy urodzin i 50-lecia pracy naukowej, red. M. Chrost i K. Jakubiak, Kraków 2018, s. 502. 
i samoistnie, ale poprzez podjęcie i zaangażowanie się w proces wychowania i samowychowania. Człowiek kształtuje myślenie refleksyjne w ciągu całego życia, tym samym ma wystarczająco dużo czasu, aby to zadanie rozwojowe mogło być zrealizowane.

\section{Podsumowanie}

Współczesny świat charakteryzuje się dużą zmiennością, niepewnością, złożonością oraz niejednoznacznością. Występujący i postępujący kult szybkiego i efektywnego działania powoduje, że nie zawsze osoby refleksyjnie nastawione do życia są akceptowane i właściwie wspierane. A przecież refleksyjność i autorefleksyjność są procesami, które sprzyjają roztropnemu, rozważnemu oraz skutecznemu działaniu. Niewątpliwie refleksja pozwala na rozumienie danej sytuacji i korzystanie $\mathrm{z}$ informacji zwrotnych $\mathrm{w}$ celu zmiany czy też modyfikacji swojego zachowania i strategii działania. Tym bardziej, że dostrzegalne współcześnie deficyty refleksyjności budzą niepokój dotyczący indywidualnego rozwoju osoby. $Z$ pewnością pozytywnym i ważnym następstwem refleksyjności jest m.in. dojrzałość społeczna, emocjonalna, wolicjonalna i duchowa. Dlatego tak ważne jest przełamywanie stereotypów, przeciwstawianie się narzuconym modom i stylom, które proponuje współczesna cywilizacja informatyczna. Tym bardziej, że coraz częściej można zaobserwować „tendencje do tego, by podstawą życia było czerpanie doznań i przyjemności, a wartości są uznawane o tyle, o ile przyczyniają się do tworzenia doznań. Konsekwencją tego jest konsumpcjonizm, a także brak systemu norm moralnych czy zupełny relatywizm i hedonizm"23. A to niszczy autentyczne wartości, spłaszcza styl życia człowieka, wymusza pogoń za dobrobytem i daje niestety pozorne poczucie szczęścia ${ }^{24}$. Refleksja jest źródłem poszukiwania sensu istnienia, ciągłego rozpoznawania własnej drogi, siłą w walce o własne człowieczeństwo. Dlatego ważne wydaje się motywowanie człowieka do kształtowania postawy refleksyjności i wspieranie go w realizacji tego rozwojowego zadania. Postulat rozwijania refleksyjności, którego celem byłoby kształcenie

A. Regulska, Rola wartości moralnych w procesie wychowania, dz. cyt., s. 149.

24

Por. M. Jagiełło, Spotkania, które zmieniają. O spotkaniu jako kategorii pedagogicznej i wydarzeniu wychowującym na drodze życia, dz. cyt., s. 9. 
myślących, zdolnych do refleksji nad życiem, świadomych siebie i znających swoje możliwości osób, oraz gotowych do podejmowania decyzji na podstawie posiadanego systemu wartości i dostosowujących swoje działanie do aktualnych warunków społecznych, powinien stać się źródłem inspiracji oraz wyzwaniem do rozwiązywania i pokonywania trudności wynikających z aksjonormatywnego chaosu współczesnego świata.

\section{Bibliografia}

Bard A., Soderquist J., Netokracja. Nowa elita wtadzy i życie po kapitalizmie, przeł. P. Cypryański, Wydawnictwa Akademickie i Profesjonalne, Warszawa 2006.

Chrost M., Autorefleksyjnośc elementem samowychowania, w: Wychowanie Socjalizacja - Edukacja. Ksiegga Jubileuszowa dedykowana prof. dr. hab. Andrzejowi Michatowi de Tchorzerwskiemu z okazji 75. rocznicy urodzin i 50-lecia pracy naukowej, red. M. Chrost i K. Jakubiak, Wydawnictwo Naukowe Akademii Ignatianum w Krakowie, Kraków 2018, s. 493-505.

Chudy W., Refleksja, w: Encyklopedia pedagogiczna XXI wieku, t. 5, red. T. Pilch, Wydawnictwo Akademickie „Żak”, Warszawa 2006, s. 68-72.

Dróżka W., Kategorie analityczne w badaniach pedeutologicznych w świetle zatożeń refleksyjnych nurtów poznawczych w naukach spotecznych, „Chowanna" 2006, t. 1(26), s. 26-48.

Gara J., Egzystencjalna problematyzacja poszukiwania, poznawania i tworzenia samego siebie, „Przegląd Pedagogiczny” 2017, nr 2, s. 9-33.

Hejnicka-Bezwińska T., Pedagogika ogólna, Wydawnictwa Akademickie i Profesjonalne, Warszawa 2008.

Jagiełło M., Spotkania, które zmieniaja. O spotkaniu jako kategorii pedagogicznej $i$ wydarzeniu wychowujacym na drodze życia, Oficyna Wydawnicza „Impuls”, Kraków 2012.

Kielar-Turska M., Rozwój cztowieka w petnym cyklu życia, w: Psychologia. Podręcznik akademicki, t. 1: Podstawy psychologii, red. J. Strelau, Gdańskie Wydawnictwo Psychologiczne, Sopot 2003, s. 313-314.

Langer E., Problemy uświadamiania. Konsekwencje refleksyjności i bezrefleksyjności, w: Poznanie. Afekt. Zachowanie, red. T. Maruszewski, Wydawnictwo Naukowe PWN, Warszawa 1993, s. 137-179.

Lasocińska K., Niecodzienna codzienność - globalizacja wyzwaniem do refeksyjnego konstruowania wtasnej biografi, „Civitas Hominibus. Rocznik Filozoficzno-Społeczny” 2011, nr 6, s. 46-50.

Pietrasiński Z., Mądrośc, czyli świetne wyposażenie umystu, Wydawnictwo Naukowe „Scholar”, Warszawa 2001. 
Przybył I., Refleksje profesora Zbigniewa Tyszki nad cztowiekiem i rodzina XXI wieku, „Roczniki Socjologii Rodziny” 2005, t. 16: Dylematy wspótczesnych rodzin, s. 245-249.

Regulska A., Rola wartości moralnych w procesie wychowania, „Studia nad Rodziną" 2013, t. 17, nr 1(32), s. 143-150.

Słaba D., Wokót zagadnień refleksyjności w rozwoju cztowieka dorostego, „Chowanna" 2014, nr 2(43), s. 321-338.

Stownik jezyka polskiego, red. M. Szymczak, Wydawnictwo PWN, Warszawa 1981.

Sternberg R.J., Images of Mindfulness, „Journal of Social Issues” 2000, nr 56, s. 11-26.

Sujak E., Rozważania o ludzkim rozwoju, Wydawnictwo Znak, Kraków 1987.

Wallerstein I.M., Koniec świata jaki znamy, przeł. M. Bilewicz, A.W. Jelonek, K. Tyszka, Wydawnictwo Naukowe „Scholar”, Warszawa 2004.

\section{ADRES DO KORESPONDENCJI:}

Dr Marzena Chrost

Akademia Ignatianum w Krakowie

Wydział Pedagogiczny

Instytut Nauk o Wychowaniu

e-mail: marzena.chrost@ignatianum.edu.pl 